\title{
Building the Global Fiber Optics Superhighway
}




\section{Building the Global Fiber Optics Superhighway}

C. David Chaffee

Chaffee Fiber Optics Ellicott City, Maryland 
eBook ISBN: $\quad$ 0-306-46979-0

Print ISBN: $\quad$ 0-306-46505-1

(C)2002 Kluwer Academic Publishers

New York, Boston, Dordrecht, London, Moscow

All rights reserved

No part of this eBook may be reproduced or transmitted in any form or by any means, electronic, mechanical, recording, or otherwise, without written consent from the Publisher

Created in the United States of America

Visit Kluwer Online at: $\quad$ http://www.kluweronline.com

and Kluwer's eBookstore at: http://www.ebooks.kluweronline.com 


\section{To Katie and Caroline}




\section{Acknowledgements}

I would like to thank the following for their insight, encouragement, and general support in helping me write this book.

At the top of the list are Kluwer Academic/Plenum editors Tom Cohn and Anna Bozicevic, without whom this book truly would not have been written. Tom, who has since left the company, had the good grace to listen stoically to my rantings about the exploding fiber optics industry one evening in a beverage line at OFC '98, and the rest, as they say, is history. Anna Bozicevic has been a steadying source, whose encouragement has kept the project on course.

Of the many others who also helped immeasurably, I would like to thank Ken Taylor and Larry Johnson for encouraging me to write this book. Both are industry pros who understand the importance of getting the message out. Others who provided expertise include Mike Newsom, Loreli Lees, Cindana Turkatte, Tom Phillips, Steve and Jeff Montgomery, Kevin Tanzillo, Mike Peppler, Duane Piersoll, Paul Rogoski, John Knight, Lawrence Gasman, Loren Talley, Rich Moran, C. David Broecker, Kathleen Coplien Szelag, Pat Robinson, Hans Ehnert, Steve McAbee, Joe Berthold, Barbara Duchez, Mike Unger, Jim Chiddix, Mark Lauroesch, Dave Pangrac, Philip Bell, Julie Unger, Konnie Schaefer, Roger Baker, Garry Adams, Steve Clements, Dr. Don Keck, Cary Bloom, Whit Cotten, John Ryan, James Shaw, Sara Herlihy, Diane Burness, Greg Wortman, Charlie Long, Jennifer Rice, Gordon Lamb, Takashi Touge, Matthew McGuinness, Bill Beck, Mike Mattei, Shelley Grandy, Robie Cline, Peter Westafer, Roger Linscott, Derek Lawrence, Kurt Ruderman, Rachel Woodford, Don Scifres, Andrew Rickman, Mike Chan, Jerry Miller, Jonathan Kraushaar, Jack Kessler, John Pittman, Fred Leonberger, and Dale Niebur.

In the 20 years that I have had the privilege of being involved in the fiber optics industry, many others have shared their time with me to give me a better understanding of the workings of this industry, many of whom are not named here but whose efforts are greatly appreciated.

I would like to thank family members, including my sister-in-law Heide 
Lange for sharing her outstanding literary skills and my brother John, her husband, for his continuing support and counsel. I would also like to thank my sister Judi Culbertson for her inspiration and my uncle, Bartlett Hess, now departed, for his encouragement, understanding, and Godly presence.

My daughters, Katie and Caroline, to whom this book is dedicated, are a continuing joy, one that fills my life with love and humor. In them I see a bright hope for tomorrow.

Lastly I wish to thank my parents Captain Hubert Chaffee, now departed, who taught me never to undertake a task without putting everything I have into it to make sure it was done right or not at all, and my mother, Charlotte Chaffee, health now diminished, who has been an unending fount of love, hope, and encouragement throughout my life. May God hold you both in the palm of His hand.

March 2000

C. David Chaffee 


\section{Contents}

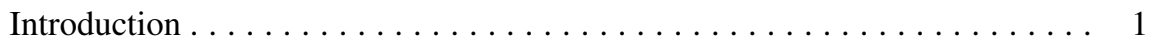

Brief Primer . . . . . . . . . . . . . . . . . . . . 7

Section 1 -The Oceans As Superhighways . . . . . . . . . . . . 13

Chapter 1: A Global Footprint . . . . . . . . . . . . . . . . . . 17

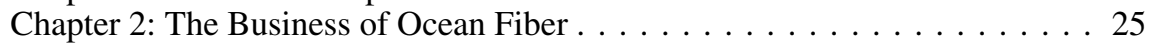

Section 2 -North America . . . . . . . . . . . . . . . . . . 31

Chapter 3: The Rerewiring of America . . . . . . . . . . . . 35

Chapter 4: Fiber Sprouts in Mexico . . . . . . . . . . . . . . . . 57

Chapter 5: The Canadian Presence .................... 61

Chapter 6: Bandwidth As Precious Commodity . . . . . . . . . . . . 71

Section 3-The Far East . . . . . . . . . . . . . . . . . . . . . . 77

Chapter 7: Japan's Twenty-First-Century Infocommunications Society . . . . 81

Chapter 8: The Competition Down Under . . . . . . . . . . . . . . 91

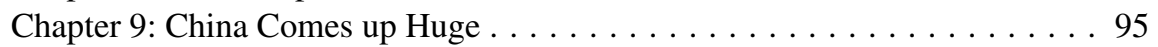

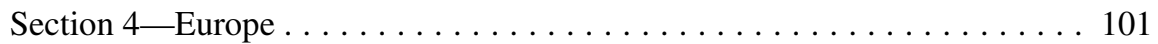

Chapter 10: Deregulation Shakes the Continent . . . . . . . . . . . . . 105

Chapter 11: The U.K. Testbed . . . . . . . . . . . . . . . . . 107

Chapter 12: Deutsche Telekom: Fibering the East, Fighting

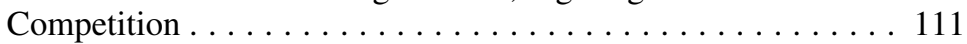

Chapter 13: France Adjusts—at Times Painfully . . . . . . . . . . . 115 
Section 5-South America . . . . . . . . . . . . . . . . . . . . . . . 119

Chapter 14: A Continent Demanding to Keep up . . . . . . . . . . . . . . . . . . 121

Section 6-An Enlightened Global Community . . . . . . . . . . . . . . . . 127

Chapter 15: Instantaneous Global Communications . . . . . . . . . . . . . . . . 129

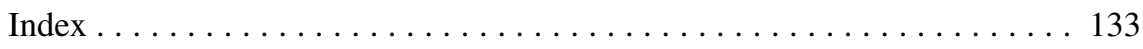

